\title{
SOMEONE BETWEEN: ETHICAL AND MEDICAL PROBLEMS OF HUMAN AND (NON)HUMAN ANIMAL ENHANCEMENT
}

\author{
AGNIESZKA ŻOK ${ }^{1}$ AND EWA BAUM ${ }^{2}$ \\ ${ }^{1}$ Poznan University of Medical Sciences, Department of Social Sciences and the Humanities, Rokietnic- \\ ka 7, 60-806 Poznań, Poland. ORCID: 0000-0002-5560-5432, Email: agzok@ump.edu.pl \\ ${ }^{2}$ Poznan University of Medical Sciences, Department of Social Sciences and the Humanities, Rokietnic- \\ ka 7, 60-806, Poznań, Poland. ORCID: 0000-0002-0503-0562, Email: ebaum@ump.edu.pl
}

ABSTRACT: Human dreams of a long and healthy life are becoming increasingly real. The advancement of medical technology allows to modify the genome or personalised therapy in order to avoid troublesome side effects. This process also leads to the blurring of boundaries between humans and animals. Rats with induced human diseases are used for testing drugs for incurable illness; humanised pigs can donate organs that are compatible with the genome and immune system of the recipient. A brave new human is approaching, and new "human" animals are making this possible. The main objective of the article is to show the differences between the refinement of people and other animals and to analyse this phenomenon from an ethical point of view. KEYWORDS: bioethics, animal ethics, posthumanism, transplantation

\section{INTRODUCTION}

The accelerated development of technology and biomedical sciences is inevitably making an impact on humans. Both the length and quality of human life have changed over the last century (Lancaster 1990; Stomma 2008). At the same time, humans are increasingly marking their domain over Earth, creating new forms of life. Dubbed "liminal lives" by Susan Squier (2004), these have come to existence following biotechnological experiments in controlled laboratory conditions (Bakke 2014). 
The concept of the Anthropocene, which describes this situation, is becoming more and more apparent in scientific reflection. The situation provokes questions about people's place in the world and their relationship with other animals and the environment. Is the human right to use the planet and others unlimited? How far can we go in using other animals to extend human life, or even to enhance people, referred to as “accelerating evolution" by transhumanists?

Bringing the Earth under human control is not a new phenomenon. Already during the transition from a hunting and gathering to a pastoral and collecting society, people changed their way of thinking and shaped plants and animals to meet their needs (Banaszak and Kmita 1994). However, never before were these changes so rapid and precise.

\section{ANTHROPOCENE}

The "Anthropocene" is a term that defines the present geological era characterised by the dominance human of activity and its effect on Earth (Waters 2016; Ellis 2018). The term was first used in the contemporary context by Paul Crutzen in 2000 (Zalasiewicz et al. 2010; Grinevald et al. 2011), suggesting that the modern era began in the second half of the $18^{\text {th }}$ century:

To assign a more specific date to the onset of the "Anthropocene" seems somewhat arbitrary, but we propose the latter part of the 18th century, although we are aware that alternative proposals can be made (some may even want to include the entire Holocene). However, we choose this date because, during the past two centuries, the global effects of human activities have become clearly noticeable. This is the period when data retrieved from glacial ice cores show the beginning of a growth in the atmospheric concentrations of several "greenhouse gases”, in particular, $\mathrm{CO}_{2}$ and $\mathrm{CH}_{4}$. Such a starting date also coincides with James Watt's invention of the steam engine in 1784 (Crutzen 2002).

The International Commission on Stratigraphy (ICS) or the International Union of Geological Sciences (IUGS) have not yet approved the term "Anthropocene" as the official name of the current geological period (Subramanian 2019), it is nonetheless commonly used in the scientific literature. The dispute over the Anthropocene primarily concerns the identification of a point in history when the Earth had actually changed. Simon L. Levis and Mark. A. Maslin suggest that 1610 marks the onset of the new era. In their opinion, the arrival of Europeans in America irreversibly affected the planet (Lewis 2015). In 2019, the Anthropocene Working Group (AWG) was established to define the beginning of the era. Among the 34 members of the AWG panel, 29 voted in favour of using the term as of the mid- $20^{\text {th }}$ century, when the rapidly growing human population stepped up the rate of industrial production, the use of agricultural chemicals and other human activity. Their decision was also affected by the use of nuclear weapons, resulting in radioactive debris that became embedded in sediments and glacial ice, becoming part of the geologic record. The panel is currently planning to submit a formal proposal to determine the start of the new epoch by 2021 to the 
International Commission on Stratigraphy, which oversees the official geologic time chart (Subramanian 2019).

Another element that proves irreversible human interference in nature is the decline in the diversity of the species that inhabit the planet. Today we are left with a relatively depauperate fauna, and we continue to lose animal species to extinction rapidly. Although some debate persists, most of the evidence suggests that humans were responsible for the extinction of this Pleistocene fauna (Vignieri 2014). For example, in the last two decades, Europe has seen a considerable decline in the population of the House Sparrow (Passer domesticus). In the Netherlands, the birds have been put on the red list of endangered species. The cause of this can be contributed to the thermal insulation of buildings (Marchowski 2015), which prevents the sparrows from nesting, as well as the use of chemical plant protection agents or lack of access to grain due to changes in corps storage (Leasure 2013).

\section{(NON)HUMAN ANIMAL ENHANCEMENT}

Human control of nature is also apparent in the desire to enhance people and in genetically adapting animals to human needs. According to transhumanists, humans, as they are today, are only in a transitional stage towards their future form. Already two decades ago, Nic Bostrom and David Pearce initiated the project Humanity+, whose roots can be traced to the French post-structuralists (Bakke 2010; Loba 1999; Miś 1994), but not until now were the goals of the project likely to come into effect. The central tenets of transhumanism are contained in the Transhumanist Declaration, published in 1998 by the World Transhumanist Association. The Declaration stresses the transhumanists' enthusiasm for state-of-the-art technologies which will influence radical changes in humans (Humanity+ 1998). The anticipated changes are to impact on nearly all aspects of human life: life span, physical and intellectual ability, as well as the creation of artificial intelligence. Recent scientific discoveries make it possible to accomplish the transhumanist visions, for instance, the controlling of heredity in an increasingly foreseeable way due to IVF mitochondrial transfer or CrisprCAS9 (Żok 2018). Whilst bioethicists display an extremely opposite approach to the possibility of treating humans by way of genome editing, in principle the disputes concern differences in deontological and consequentialist reasoning. It is, nonetheless, indisputable that the reason for reprogenetics research is to improve human health and quality of life. On the other hand, from a post-humanist point of view, doubts arise from the fact that all medications and technologies that allow people to enjoy a long life and good health are, before being used in therapy, tested on animals. Additionally, deeper insight into the molecular foundations of life reveals a genetic similarity between humans and non-human animals, opening the possibility of matching the similarity to fit human needs. Animal enhancement takes place on two levels: animals are modified to be more useful to people and to use them to test therapies aimed at improving the quality of human life. Subsequently, animal enhancement serves a completely different purpose than human enhancement; hence the ethical evaluation of this procedure can be entirely different. Developments in biotechnology over the past 25 years 
have allowed scientists to engineer genetically modified (GM) animals that are used in agriculture, medicine and homelife. An example of animal enhancement to better serve human needs is the modification of dairy cows or chicken to raise their productivity. These modified animals should also gain weight faster or be immune to diseases caused by intensive animal farming. Despite such a rationale, the changes cause the animals to suffer. For example, the joints of chicken often cannot withstand their weight (Forabosco et al. 2013; PETA 2017).

Another example of animal enhancement is laboratory animals modified to be animal models for human diseases. Although the use of anatomy and physiology began in ancient Greece, the discoveries of the New Genetics have allowed for lasting and more useful improvement of animals (Ericsson et al. 2013).

The most widespread response among both medical researchers and ethicists was brought about by the creation of the oncomouse at Harvard University in $1984^{1}$. Inducing human breast cancer cells into mouse embryos created an animal that is vulnerable to oncological diseases. The model is currently used in preclinical trials of oncological therapies. Another example are animals with induced diabetes, depression or Huntington's disease. From the point of view of basic and pharmaceutical research, these animals provide an ideal research model for specific diseases.

However, another example of using animals to advance medical research is a specific group of transplantation procedures, namely xenotransplantation (also called heterogenous transplantation). The procedures consist of transplantation between two different species. According to the definition of the U.S. Public Health Service:

Xenotransplantation is now defined to include any procedure that involves the transplantation, implantation, or infusion into a human recipient of either (a) live cells, tissues, or organs from a non-human animal source or (b) human body fluids, cells, tissues or organs that have had ex vivo contact with live nonhuman animal cells, tissues, or organs. Furthermore, xenotransplantation products have been defined to include live cells, tissues or organs used in xenotransplantation. The term xenograft, used in previous PHS documents, will no longer be used to refer to all xenotransplantation products ${ }^{2}$.

Due to a shortage of organs and limited possibilities of conducting allotransplantations $^{3}$, xenotransplantation is used as an alternative solution, which is, nonetheless, controversial in terms of medical, as well as ethical, social, legal and religious considerations.

The medical success of xenotransplantation is limited due to the risk of hyperacute rejection of the transplanted tissue or organ by the recipient's body, which may be a source of medical complications (Rowiński et al. 2014). Primarily, this includes the risk of transferring animal pathogenic factors onto humans. Simultaneously, nonmed-

\footnotetext{
${ }^{1}$ European Patent Register entry for European patent no. 0169672, under Inventor(s). Consulted on February 22, 2008.

${ }^{2}$ U.S. Public Health Service Guideline on Infectious Disease Issues in Xenotransplantation. Retrieved August 4, 2019 (https://www.cdc.gov/mmwr/preview/mmwrhtml/rr5015a1.htm).

${ }^{3}$ Allotransplantation (homotransplantation) is transplantation within one species.
} 
ical philosophical concerns identify the potential risk of manipulating animal organs, which specifically refers to the so-called humanised pigs ${ }^{4}$ (Bohatyrewicz 1991; Kościelniak 2005) or to using monkeys (especially baboons as heart donors and chimpanzees as liver donors). The first xenotransplantation procedure was performed in Russia in 1682 , where a piece of a dog's skull was used to replace a missing skull fragment in a wounded $\operatorname{man}^{5}$ (Smorąg et al. 2011). The actual development of experimental transplantation medicine, including transplantation of animal grafts, began in the early 1920s. It is estimated that between 1906-1995, 70 animal-to-human transplantations were performed (Daar 1999). The best known and controversial xenotransplantation procedure was conducted in 1984 by Leonard Bailey, who attempted to transplant a heart from a baboon to a baby. In literature, this is known as the case of Baby Fae, named so to protect the family's anonymity. The procedure garnered a widespread reaction when the patient died within 20 days. According to many respondents, the procedure was unwarranted, no alternative treatments were sought, nothing was known about the parents' informed consent, and doctor Bailey was reluctant to work with the media (Borowiec 2019; Tilney 2019).

In Poland, since 2003 the Institute of Zootechnics in Balice has been conducting research on transgenic pigs, supervised by prof. Zygmunt Smorąg. The project, ordered by the Ministry of Science and Informatisation, involves 11 research teams representing various fields, including molecular biology, embryology, virology, immunology, as well as transplantation surgery. The project aims to breed transgenic pigs with an edited human gene in order to crossbreed the animals to obtain the best possible transplantation organ, and thus, to lower the immunological barrier between humans and pigs (Smorąg and Słomski 2005). So far, the outcome of the project is the TG1154 transgenic hog, whose semen is used to inseminate and reproduce subsequent specimens. Professor Smorąg stresses the importance of various procedures and requirements regarding how xenotransplantation products are obtained. A major requisite is the source of organs and their effectiveness which leads to appointing a specific series number, as well as their safety with regard to their maximum and documented sterility (Smorąg 2006). Indisputably, the advantage of xenotransplantation is that it responds to the human organ shortage, in addition to the possibility of thoroughly testing, supervising and fully controlling a specific graft (i.e. its size and genetic profile), as well as specifically planning transplantation procedures.

Apart from biotechnical, medical and organisational aspects, xenotransplantation involves social and ethical concerns. By their very nature, xenotransplantation gives rise to moral dilemmas. Most people approach the use of heterogenous organs with reserve. Some fear the existence of an alien, heterogenous organ inside the human body: the most perfect, most advanced evolutionary organism. Others are simply afraid of rejection or inefficiency of the animal graft. Western European societies clearly differ-

\footnotetext{
${ }^{4}$ Xenotransplantation has, for some time, been perceived as an equivalent alternative to allotransplantation. See: Kościelniak P., Transgeniczne wnuki, „Rzeczpospolita”, 06.12.2005.

${ }^{5}$ Smorąg et al. 2011. On the other hand, different sources claim that the first dog-to-human bone transplantation was performed in 1501 in Iran. See: Umana 1995:1481.
} 
entiate between organs in respect to their species of origin. Considerably less controversial is the use of transgenic animals, for instance bred organs from pigs, than using organs from monkeys, despite their anatomic and physiologic similarity to people. Primates seem especially close to the human species due to the affinity between them (being the closest phylogenetically related). This, however, raises some concerns, as the relatively high level of compatibility means that some baboon and chimpanzee viral pathogens can infect people (Smorąg and Słomski 2005). Moreover, the breeding of monkeys is more demanding. Their fertility is much lower and gestation longer in comparison to pigs, which have turned out to be the optimal animals.

Furthermore, public discourse attaches great importance to religious issues. The three monotheistic religions (Judaism, Christianity and Islam) accept xenotransplantation, allowing the use and modification of nature (including the animal world) if this serves the development and welfare of humankind. Humans have the right to intervene in the work of God. Moreover, Islam and Judaism accept pig xenotransplantation, because they do not see this as the consumption of meat, but as a considerable advantage resulting from using animal organs (Smorąg 2011).

In the Catholic Church, already in 1956 Pope Pius XII spoke of xenotransplantation in his address to the Italian Corneal Donors Association and the Italian Blind Association, stating that it is acceptable when the transplanted organ does not violate the recipient's mental and genetic identity, and the risk associated with the procedure is relatively small (Kniaź 2005). Nonetheless, it should be stressed that the Catholic Church has spoken against xenotransplantation in relation to gonads and brain cells (Smorąg 2011).

Some other religions, for instance, Buddhism and Hinduism, have different perceptions of the relationship between humans and animals, whilst concerns regarding animal organ transplants are left to the believers' individual judgement. In addition, cultural factors play a significant role in the acceptance of xenotransplantation in countries where post-mortem allotransplantation is not possible from a social point of view. For example, in Japan and India organ transplants from animals are a feasible alternative, but the opponents of these procedures cite various arguments against them, including philosophical, legal and medical factors. Of significance are also the above-mentioned arguments concerning the pursuit of anthropocentrism at all costs, and the utilitarian nature of such activity when animals become a "reservoir of spare parts" for people. Other issues involve potential problems with the recipient's identity and concerns relating to the "tyranny of the gift".

In general, transplantation is usually perceived as a gift (Chyrowicz 2011), as an informed and fully voluntary decision. But can we really speak of informed decisions in the case of animals? Could the moral dilemma that is harvesting animal organs be solved by measures taken to increase the number of allotransplantations? These

\footnotetext{
${ }^{6}$ The term was used in a somewhat different context by prof. Szawarski in an interview conducted by Jakub Kowalski: Kowalski J., Odwaga rezygnacji, „Rzeczypospolita”, Człowiek i nauka, z dn. 26.11.2003. In the case of animal organ transplantation, the "tyranny of the gift" may mean a burden that is hard to bear by the potential recipient due to the actual source of the organ.
} 
measures should target the largest possible groups of recipients to reliably present to them the dangers of organ donation, in addition to making them aware that transplantation is a lifesaving procedure which has no other substitute (Baum 2017). Using animal organs would not be necessary if there was a significant increase in donations from relatives and other unrelated living donors ${ }^{7}$.

Legal issues are also a cause of concern as the recipient loses at least some of their rights to anonymity and privacy, whilst being obliged to inform the people around them (including the medical community) of having a xenograft in their body (Smorąg 2006). This may cause the organ recipient to feel discomfort and a sense of discrimination. Another legal aspect is the possible existence of "xenotourism", in other words, organised and commercial journeys to countries where xenotransplantation is possible $^{8}$. Nowadays, another example of controversial ethical research is creating animal embryos that contain human cells and transplant them into surrogate animals. The study was approved in 2019 in Japan (Cyranowski 2019).

Xenotransplantation should, therefore, be perceived not only from the anthropocentric perspective, which refers mainly to the risk of rejection of the heterogenous transplant but also from the point of view of ecology ethics where the major aspects include animal welfare and avoidance of unnecessary pain and stress. Furthermore, the decision to perform xenogeneic transplantation should be preceded by a thorough analysis of the potential gains and risks. In addition, alternative methods should be considered, as well as the specific patient's choice (Smorąg and Słomski 2005).

\section{SUMMARY}

Today, scientists who use animals in scientific research must meet a range of criteria established in EU directives and local laws (Żok 2019) to provide the animals with an appropriate level of wellbeing (Mamzer 2016). However, the aim of the research is not to improve the health of the animals. First of all, the actual term "animal enhancement" is ambiguous, since the wellbeing of the "enhanced" animals is very much reduced. In human enhancement, the situation is clear: humans decide for themselves which traits are evolutionarily desirable, and which should be discarded. Thus, animal enhancement happens from an extremely anthropocentric standpoint whereby people decide how to change the animal genome, guided by their own profit. Reservations concerning human enhancement result mainly from the historical implications of eugenics. It is worth noting that in this context, humans are autonomous agents (Żok, Baum 2018), whereas the same cannot be said of animals. The dispute around using animals in this way is apparent both in debates about eating animals and their mass breeding, as well as using them in laboratories. The ethical evaluation of animal en-

\footnotetext{
${ }^{7}$ In 2018, only 23 liver transplantations from living donors and 295 from deceased donors were carried out in Poland. See: Poltransplant, http://www.poltransplant.org.pl/statystyka_2018.html.

${ }^{8}$ The issue is analogical to the functioning of the so-called "black market for organs".

${ }^{9}$ In this respect, the concept of wellbeing is regarded from various perspectives, including the following areas: somatic, physiologic, behavioural, emotional, cognitive, psychological and social. The areas overlap and are inherently connected by complex and reciprocal interactions. See: Mamzer 2016.
} 
hancement will, therefore, depend upon the adopted ethical standpoint.

The first approach is that of human domination (Szewczyk 2009), which is extremely anthropocentric based on the belief that only humans can feel pain and emotions and have a consciousness. Nowadays, this assumption does not seem accurate, because there is no doubt the non-human animals can feel pain and emotions. Furthermore, this approach does not seem to benefit humans. The Anthropocene era ${ }^{10}$, where people have strongly marked their existence on Earth, has led to global warming and littering the planet.

An opposing approach, codified by Tom Regan, emphasises animal rights. Furthermore, Peter Singer advocates treating people and animals with equal respect. Referring to the philosophy of Jeremy Bentham, Singer situates his theory in direct opposition to the Cartesian assumption of absolute human domination. Both humans and non-human animals have the ability to feel pain; therefore, all beings have equal rights to be free from suffering. In The Case for Animal Rights (Szewczyk 2009), Regan notes that all sentient beings have basic rights and interests that should not be violated. Most importantly, making such beings suffer should not be allowed, and subsequently, people are obliged to take care of animal welfare. Accordingly, Regan believes that anthropocentric research on animal enhancement excludes the animals' basic rights.

Yet another approach supports the priority of human interests over animal rights. Consequently, researchers can use animals but should minimise their suffering and reduce their numbers in experiments (Szewczyk 2009). The proponents of experiments on animals believe that most achievements in medical sciences up to the late $19^{\text {th }}$ century would not have been possible if biomedical research did not use animals (Mephan 2008). Subsequently, animal enhancement leads to an important gain for humans. The organs grown on humanised animals can considerably improve the quality of life of people awaiting transplantation.

As a tenet of the Anthropocene, endeavours to adapt Earth to meet human needs include the adapting of non-human animals. The ethical assessment of this phenomenon will depend on the actual advantage for humans, caring for the modified animals' welfare and the ecological impact of such organisms on the environment.

Another problem is the fluidity of transition between bodies. Human cells are implanted in other animals, allowing to grow organs used in transplantation or to increase the efficacy of tested therapies in humans. With this approach to genetically modified animals, an appropriate concept would be that of "biopower" used by Foucault and Donna Haraway.

The latter compares the hierarchy of organisms to patriarchal or oedipal family narratives (Haraway 1997; Braidotti 2006). This understanding of speciesism constitutes an important rationale in contemporary philosophy. In their undefined status, the concepts of "cyborg", "coyote", "trickster" and "oncomouse" disrupt this discourse.

\footnotetext{
${ }^{10}$ The concept of the "Anthropocene" is used to describe the contemporary geological age. The Anthropocene narrative presents humanity as a species taking control of the rest of the Earth System. See: Malm and Hornborg 2014.
} 
Haraway sees the oncomouse as a technical body par excellence: it was created to serve profitable trade between the laboratory and the market, between patent offices and research centres (Haraway 1997). On the other hand, Haraway emphasises the kinship between transgenic animals and humans by calling the oncomouse her sister (Haraway 1997). Citing the oncomouse as an example, Haraway also notes that transgenic animals are becoming contemporary Christs who sacrifice themselves for people. The sacrifice of the oncomouse and other transgenic animals will, for instance, give many women a chance to recover from diseases that, until now, did not prognoses well.

Moreover, transgenic animals disturb the "culture vs. nature" opposition. Animal reproduction is removed from the natural process and takes place with laboratory precision to increase its usefulness. This enmeshed approach to the oncomouse is characteristic of Haraway's project, which includes both cognitive and ethical aspects. It consists in thinking across established categories, for example, "nature vs culture" or "human-made vs human-born". But it is also a criticism of commodity fetishism and the so-called "market economy" in its corporate and global stadium.

With regard to ethics, the project concerns a new system of affinity to or new forms of social connections with "techno-others" (Braidotti 2006a). In the context of relationships resulting from affinity, the question arises of the relationship between the organ recipient and the animal carrier. To use Haraway's metaphor, the animal, in this instance, ceases to be the recipient's mythical sister actually to become their daughter created directly from their genetic material. This leads to a new relationship between the donor and the recipient, and those existing until are now, in this case, no longer of use (Baum and Wiertlewska-Bielarz 2012). Nonetheless, from an ethical point of view, it is difficult to treat the animal as an object. Despite prioritising human interest in medical sciences, the animal has to remain important in this relationship. On the one hand, it becomes the embodiment of the post-humanist understanding of the human-animal unity and symbiosis, whilst on the other, it deepens the anthropocentric relationship whereby humans are able to control natural processes and increase their biopower with respect to nature.

Moreover, Jurgen Habermas observes that the non-human is approached with enthusiasm, as well as fear of potentially losing one's position in the centre of the world (Habermas 2003). Experiments consisting of raising the genetic affinity between non-human animals and humans blur the differences between them, whilst reinforcing human domination on Earth. At their core, medical, philosophical, ethical and social concerns refer to the problem of objectified animal sacrifice and their suffering to the advantage of humans, which in reality is a dispute between value systems. Within this dispute, it is important to remember the anthropomorphism, evolutionary affinity, social relationships and intelligence of animals, so that the so-called "Thrasymachus Law" (Plato 2003), where justice is seen as the "interest of the stronger", does not determine our humaneness. 
FUNDING: This research received no external funding.

CONFLICT OF INTEREST: The authors declare no conflict of interest.

\section{REFERENCES}

Bakke, Monika. 2014. „Biotechnologiczne zwierzę. Zwierzęta jako tkanki, komórki i genomy.“ Pp. 77-85 in Zwierzęta, gender, kultura. Perspektywa ekologiczne, etyczna $i$ krytyczna, edited by A. Barcz and M. Dąbrowska. Lublin: E-naukowiec.

Bakke, Monika. 2010. Bio-transfiguracje. Sztuka i estetyka posthumanizmu. Poznań: Wydawnictwo Naukowe UAM.

Banaszak, Grzegorz and Jerzy Kmita. 1994, Społeczno-regulacyjna koncepcja kultury. Warszawa: Instytut Kultury.

Baum, Ewa. 2017 Jakość życia chorych poddawanych terapii nerkozastępczej. Poznań: Wydawnictwo Naukowe Uniwersytetu Medycznego w Poznaniu.

Baum, Ewa and Jadwiga Wiertlewska-Bielarz. 2012. „Z czyjej perspektywy dyskutować o legalizacji handlu narządami?” Przegląd Filozoficzny. Nowa Seria 2(82): 141-150.

Bohatyrewicz, Romuald. 1991. „Zagadnienia towarzyszące przeszczepianiu narządów.“ XXXI Anestezjologia Intensywna Terapia. Organ Polskiego Towarzystwa Anestezjologii i Intensywnej Terapii, 1 , suplement I.

Borowiec, Tomasz. 2019. Ksenotransplantacje aspekty prawne i etyczne. Warszawa: Diffin.

Braidotti, Rosi. 2006. "Posthuman, All Too Human. Towards a New Process Ontology." Theory, Culture \& Society 23(7-8): 197-208. Retrieved August 10, 2019 (http:// tcs.sagepub.com/ content/23/7-8/197.full.pdf+html).

Chyrowicz, Barbara, ed. 2011. Transplantacje: spór o dar. Lublin: Towarzystwo Naukowe Katolickiego Uniwersytetu Lubelskiego Jana Pawła II.

Crutzen, Paul. 2002. "Geology of mankind." Nature 415(23): 6867. DOI: https://doi. org/10.1038/415023a

Cyranowski, David. 2019. „Japan approves first human-animal embryo experiments.” Nature 26.07. DOI: 10.1038/d41586-019-02275-3

Daar, Abdallah. 1999. "Animal-to-human organ transplants - a solution or a new problem?” Bulletin of the World Health Organization 77(1): 54-61.

Ellis, Erle. 2018. Anthropocene: A Very Short Introduction. Oxford: Oxford University Press.

Ericsson, Aaron C., Marcus Crim and Franklin Craig. 2013. „Brief History of Animal Modeling." Missouru Medicine 110(3): 201-205.

Forabosco, Flavio, Mare Löhmus, Lotta Rydhmer and Fred Sundström. 2013. "Genetically modified farm animals and fish in agriculture: A review.” Livestock Science 153(1-3): 1-9.

Habermas, Jurgen. 2003. Przyszłość natury ludzkiej. Warszawa: Scholar.

Haraway, Donna. 1997.Modest_Witness@Second_Millennium.FemaleMan@_Meets_OncomouseTM. London-New York: Routledge.

Humanity+. 1998. “Transhuman Declaration.” Retrieved August 10, 2019 (https://humanityplus. org/philosophy/transhumanist-declaration). 
Kniaź, Grzegorz. 2005. „Kościół a transplantacja.” Skwierzyna Broszura Stowarzyszenia Życie po przeszczepie.

Kościelniak, Piotr. 2005. „Transgeniczne wnuki.” Rzeczpospolita 6 December.

Leasure, Douglas. 2013. "The House Sparrow Passer domesticus decline: conservation tools emerge from a contrasting North American perspective.” Indian BIRDS 8 (1): 22-23.

Lancaster, Henry. 1990. Expectations of Life. A Study in the Demography, Statistics, and History of World Mortality. New York: SPRINGER.

Lewis, Simon and Mark Maslin. 2015. “Defining the Anthropocene.” Nature 519:171180.

Loba, Mirosław. 1999. „O śmierci podmiotu trzydzieści lat później” in Człowiek i rzecz. O problemach reifikacji w literaturze i sztuce, edited by S. Wysłouch and B. Kaniewska. Poznań: Poznańskie Studia Polonistyczne.

Malm, Andreas and Alf Hornborg. 2014. "The geology of mankind? A critique of the Anthropocene narrative.” The Anthropocene Review 1(1): 62-69. DOI: https://doi. org/10.1177/2053019613516291

Mamzer, Hanna. 2016. Pojecie dobrostanu zwierząt jako kategoria transgraniczna, Poznańskie Zeszyty Humanistyczne XXIX: 8-17.

Marchowski, Domikik. 2015. Ptaki Polski. Kompletna lista 450 stwierdzonych gatunków. Warszawa: SBM.

Meera, Subramanina. 2019. “Anthropocene now: Influential panel votes to recognize Earth's new epoch.” Nature May 21. DOI: 10.1038/d41586-019-01641-5

Mephan, Ben. 2008. Bioetyka. Warszawa: PWN.

Miś, Andrzej. 1994. „O genezie współczesnego antyhumanizmu.” Pp. 51-63 in Derridiana, edited by B. Banasiak. Kraków: Inter Esse.

Peta. 2019. “Factory Farming: Misery for Animals.” Retrieved 10, August 2019 (https:// www.peta.org/issues/animals-used-for-food/factory-farming/).

Hosie, Rachel. 2017. "Inherent abuse and cruelty is standard industry practice." Independent, 4 January.

Platon. 2003. Państwo. Kęty: Antyk.

Rowiński, Wojciech, Janusz Wałaszewski and Leszek Pączek, eds. 2004. Transplantologia kliniczna. Warszawa: Termedia.

Smorąg, Zdzisław. 2016. „Biotechnologiczne, prawno-organizacyjne i etyczne aspekty ksenotransplantacji.” Biotechnologia 1(72): 103-109.

Smorąg, Zdzisław and Ryszard Słomski. 2005. „Ksenortansplantacja - możliwości i ograniczenia." Nauka 4/2005: 133-148.

Smorąg, Zdzisław, Ryszard Słomski, Jacek Jura, Daniel Lipiński, and Maria Skrzyszowska. 2011. „Transgeniczne świnie jako dawcy tkanek i narządów do transplantacji u ludzi." Przegląd Hodowlany 79(11): 1-4.

Steffen, Will, Jacquese Grinevald, Paul Crutzen, and John McNeill. 2011. "The Anthropocene: conceptual and historical perspectives.” Philosophical Transactions of the Royal Society A: Mathematical, Physical and Engineering Sciences 369(1938): 842-867.

Stomma, Ludwik. 2008. A jeśli było inaczej... Antropologia historii. Poznań: Wydawnictwo Sens. 
Squier, Susan M. 2004. Liminal Lives: Imagining the Human at the Frontiers of Biomedicine. Durham, North Carolina: Duke University Press.

Szewczyk, Kazimierz. 2009. Bioetyka. Pacjent w systemie opieki zdrowotnej, PWN, Warszawa.

Tilney, L. Nicholas. 2009. Przeszczep: od mitów do rzeczywistości. Warszawa: Medical Science International.

Tucker, Ian. 2018. “Genetically modified animals.” The Guardian. Retrieved July 32019.

Umana, Hernando R. 1995. "Grafting of bone from dog into the human skull: an historical note." Plastic and Reconstructive Surgery 96(6): 1481.

Waters, Colin N. et al. 2016. "The Anthropocene is functionally and stratigraphically distinct from the Holocene." Science 351(6269). DOI: 10.1126/science.aad2622

Vignieri, Sacha. 2014. “Vanishing fauna.” Science 354(6195): 392-395. DOI: 10.1126/ science.345.6195.392

Zalasiewicz, Jan, Mark Williams, Will Steffen and Paul Crutzen. 2010. “The New World of the Anthropocene.” Environmental Science \& Technology 44(7): 2228-2231.

Żok, Agieszka and Ewa Baum. 2018. "Eugenics in the Polish context: from racial hygiene to new genetics." Pp.490-497 in Understanding Central Europe, edited by M. Moskalewicz and W. Przybylski. Abingdon and New York: Routledge.

Żok, Agnieszka. 2019. „Bezpieczeństwo czy zniewolenie zwierząt labolatoryjnych. Czy istnieje etyka badań prowadzonych na zwierzętach.” Pp. 61-72 in Bezpieczne czy zniewolone. Szkice o zwierzętach, edited by H. Mamzer and A. Żok. Bydgoszcz: Epigram.

Żok, Agnieszka. 2018. „Troska czy opresja - współczesny dyskurs genetyczny w kontekście myśli transhumanistycznej.” Etyka 57: 87-99. DOI: https://doi. org/10.14394/37.

\section{BIOGRAPHICAL NOTE}

Agnieszka Żok is cultural expert, Doctor of Health Sciences, assistant professor in the Department of Social Sciences and Humanities at the Poznan University of Medical Sciences, Poland. Member of the Local Ethical Committee for Animal Experiments.

Ewa Baum is professor at the Poznan University of Medical Sciences, Poland. She is interested in the advancement of modern biomedicine and its accompanying ethical contexts.

OPEN ACCESS: This article is distributed under the terms of the Creative Commons Attribution Non-commercial License (CC BY-NC 4.0) which permits any non-commercial use, and reproduction in any medium, provided the original author(s) and source are credited.

ARTICLE HISTORY: Received 2019-09-04 / Accepted 2019-11-24 
